\title{
Processing of proglucagon to GLP-1 in pancreatic $\alpha$-cells: is this a paracrine mechanism enabling GLP-1 to act on $\beta$-cells?
}

\author{
N M Whalley ${ }^{1,3}$, L E Pritchard ${ }^{1, *}$, D M Smith ${ }^{3}$ and A White ${ }^{1,2}$ \\ ${ }^{1}$ Faculty of Medical and Human Sciences and ${ }^{2}$ Faculty of Life Sciences, Manchester Academic Health Sciences Centre, University of Manchester, 3.016 AV Hill \\ Building, Manchester M13 9PT, UK \\ ${ }^{3}$ Diabetes Research Group, AstraZeneca, Alderley Park, Macclesfield SK10 4TG, UK \\ (Correspondence should be addressed to A White at Faculties of Life Sciences and Medical and Human Sciences, Manchester Academic Health Sciences Centre, \\ University of Manchester; Email: awhite@manchester.ac.uk) \\ *(L E Pritchard is now at KnowledgePoint360 Group, Macclesfield, UK)
}

\begin{abstract}
Proglucagon is cleaved to glucagon by prohormone convertase 2 (PC2) in pancreatic $\boldsymbol{\alpha}$-cells, but is cleaved to glucagon-like peptide-1 (GLP-1) by PC1 in intestinal L-cells. The aim of this study was to identify mechanisms which switch processing of proglucagon to generate GLP-1 in the pancreas, given that GLP-1 can increase insulin secretion and $\beta$-cell mass. The $\alpha$-cell line, $\alpha \mathrm{TC} 1-6$, expressed PC1 at low levels and GLP-1 was detected in cells and in culture media. GLP-1 was also found in isolated human islets and in rat islets cultured for 7 days. High glucose concentrations increased Pc1 gene expression and PC1 protein in rat islets. High glucose $(25 \mathrm{mM})$ also increased GLP-1 but decreased glucagon secretion from aTC1-6 cells suggesting a switch in processing to favour GLP-1. Three G protein-coupled receptors, GPR120,

TGR5 and GPR119, implicated in the release of GLP-1 from L-cells are expressed in $\alpha \mathrm{TC1}-6$ cells. Incubation of these cells with an agonist of TGR 5 increased PC1 promoter activity and GLP-1 secretion suggesting that this is a mechanism for switching processing to GLP-1 in the pancreas. Treatment of isolated rat islets with streptozotocin caused $\beta$-cell toxicity as evidenced by decreased glucosestimulated insulin secretion. This increased GLP-1 but not glucagon in the islets. In summary, proglucagon can be processed to GLP-1 in pancreatic cells. This process is upregulated by elevated glucose, activation of TGR 5 and $\beta$-cell destruction. Understanding this phenomenon may lead to advances in therapies to protect $\beta$-cell mass, and thereby slow progression from insulin resistance to type 2 diabetes.

Journal of Endocrinology (2011) 211, 99-106
\end{abstract}

\section{Introduction}

Like many prohormones, proglucagon is processed in a cell type-specific manner. In the $\alpha$-cells of the pancreas, proglucagon is processed to glucagon by prohormone convertase 2 (PC2), but it undergoes alternative processing in the L-cells of the intestine with PC1 catalysing the cleavage to yield glucagon-like peptide (GLP)-1 and GLP-2 (Fig. 1a). Evidence suggests the tissue-specific processing is due to differential expression of PC1 (Tucker et al. 1996) and PC2 (Rouille et al. 1994).

GLP-1 is well known as an incretin hormone and its role in potentiating glucose-stimulated insulin secretion (GSIS) in response to a meal has been clearly elucidated (Edwards $e t$ al. 1999). Importantly, GLP-1 may have longer term effects on $\beta$-cell neogenesis and proliferation given that the GLP-1 analogue, exendin- 4 , increases the rate of $\beta$-cell regeneration in rats that have undergone a partial pancreatectomy $(\mathrm{Xu}$ et al. 1999). GLP-1 has also been shown to reduce $\beta$-cell susceptibility to apoptosis following exposure to streptozotocin (STZ; Buteau et al. 2004).

There is increasing interest in GLP-1 as a therapy for type 2 diabetes. However, GLP-1 is degraded by dipeptidyl peptidase IV (DPPIV) and therefore has a very short half-life (Larsen \& Holst 2005). Indeed around 90\% of the GLP-1 secreted from the L-cells is degraded before it reaches the circulation (Hansen et al. 1999). Thus, it seems unlikely that the majority of GLP-1 secreted from the L-cells acts directly on the pancreas. Studies by Ionut et al. (2006) where they infused GLP-1 and glucose into the systemic circulation and observed only a modest increase in insulin compared with that achieved by a meal, suggest that GLP-1 may be acting at least partially via the vagus nerve to stimulate insulin secretion. However, that begs the question of why there are GLP-1 receptors present on $\beta$-cells (De Leon et al. 2006) and it may be that GLP-1 can be generated locally in the pancreas and act directly on $\beta$-cells.

Other non-mammal vertebrate species, including fish and frogs produce pancreatic GLP-1 (Irwin 2001) and previous data have shown trace amounts of GLP-1 in the mammalian $\boldsymbol{\alpha}$-cell, which is increased by high concentrations of glucose (McGirr et al. 2005). However, little is known about the physiological relevance. Animal models have suggested that 


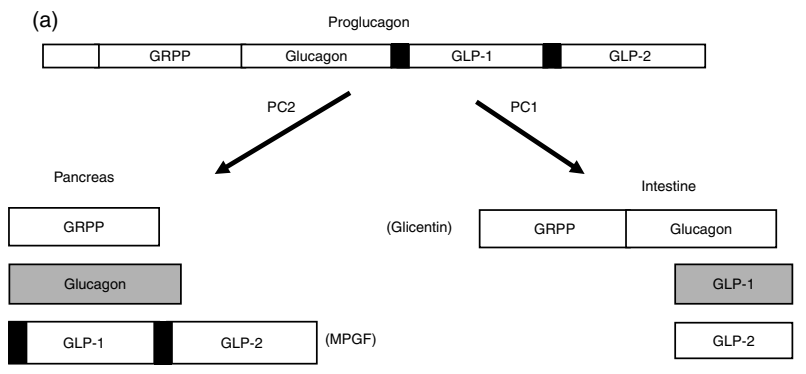

(b)
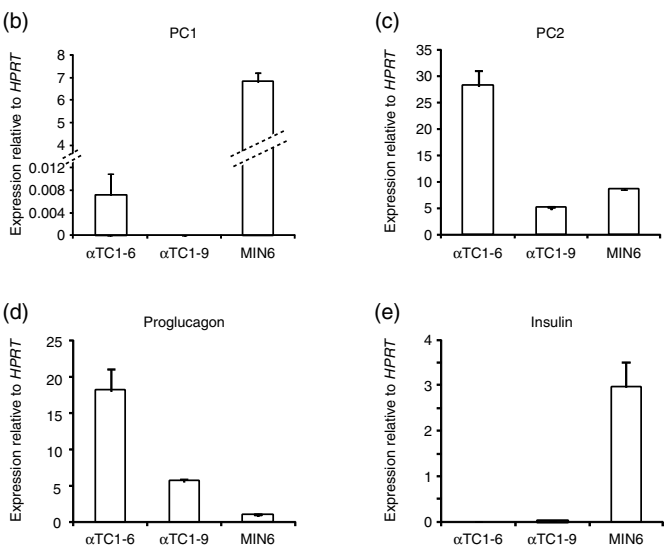

Figure 1 Expression of pancreatic islet proglucagon/proGLP-1 and prohormone convertases (PCs) in pancreatic $\alpha$-cell lines. (a) Proglucagon is processed by PC2 to mature glucagon in the pancreatic $\alpha$-cells. Proglucagon is also processed by PC1 to GLP-1 and this is known to occur in the L-cells in the intestine. (b and c) Gene expression for the convertases (PC1 and PC2), proglucagon (d) and insulin (e) were analysed in two pancreatic $\alpha$-cell lines ( $\alpha \mathrm{TC} 1-6$ and $\alpha \mathrm{TC} 1-9$ ) and a $\beta$-cell line (MIN6). Data are the mean expression of triplicate wells \pm S.E.M., normalised to the housekeeping gene $H P R T$, and are representative of three experiments.

the levels of GLP-1 increase in situations of stress on $\beta$-cells but there is no clear indication of the mechanism (Nie et al. 2000, Thyssen et al. 2006).

In considering how GLP-1 secretion could be increased, it is interesting to note that glucose stimulates release of GLP-1 from the L-cells in the intestine (Reimann \& Gribble 2002). GLP-1 is also released in response to stimulation of two G protein-coupled receptors (GPCRs), GPR120 and TGR5. TGR 5 responds to fatty acids such as linolenic acid with an increase in GLP-1 release (Kawamata et al. 2003). Similarly, stimulation of GPR120 in the STC-1 enteroendocrine cell line by $\alpha$-linolenic acid and palmitoleic acid causes secretion of GLP-1 (Hirasawa et al. 2005). Although the endogenous agonist for GPR119 is not known, a small molecule agonist (AR231453) stimulates release of GLP-1 from another enteroendocrine cell line (GLUTag) in a similar manner to forskolin (Chu et al. 2007).

In this paper, we have explored the expression of PC1 and the concentrations of GLP-1 in a pancreatic $\alpha$-cell line and isolated rat and human islets. We have investigated factors which upregulate PC1 production and then examined whether mechanisms that destroy $\beta$-cells cause upregulation of GLP-1 secretion. These intra-pancreatic events suggest an endogenous approach to counteract the destruction of $\beta$-cells in type 2 diabetes.

\section{Materials and Methods}

\section{Cell lines}

The $\alpha$-cell lines, $\alpha$ TC1-6 (a kind gift from Prof. John Creemers, University of Leuven, Belgium) and aTC1-9 along with the intestinal L-cell line STC-1 (both obtained from the American Tissue Culture Collection, ATCC, Manassas, VA, USA) were grown in DMEM (Sigma) supplemented with 10\% FCS (Invitrogen), and a 1\% mix of penicillin, streptomycin and glutamine (PSG, Invitrogen), and incubated at $37^{\circ} \mathrm{C}$ and $5 \% \mathrm{CO}_{2}$. STC- 1 cells were maintained in DMEM plus GlutaMAX (Invitrogen) supplemented with 10\% horse serum (Invitrogen), 2.5\% FCS and 1\% PSG.

\section{Quantitative PCR}

Total RNA was extracted using Qiagen Mini columns (Qiagen) and its quantity was determined by a NanoDrop spectrophotometer (NanoDrop Technologies, Wilmington, DE, USA). Total RNA of $1 \mu \mathrm{g}$ was reverse transcribed using TaqMan reverse transcriptase reagents, and random hexamer primers (Applied Biosystems, Foster City, CA, USA) and incubated at $25^{\circ} \mathrm{C}$ for $10 \mathrm{~min}, 48^{\circ} \mathrm{C}$ for $30 \mathrm{~min}$ and $95^{\circ} \mathrm{C}$ for 5 min. QPCR assays were performed on an ABI Prism 7900 TaqMan Sequence Detection system (Applied Biosystems). Primers and probes for the amplification of hypoxanthineguanine phosphoribosyltransferase (HPRT), PC1 and PC2 were designed using Primer Express 1.5a (Applied Biosystems), sequences are detailed in Table 1 . The primers and probes for the remaining genes were TaqMan Gene Expression Assays (based on published sequences (Applied Biosystems; proglucagon, mouse - Mm01269055, rat - Rn00562293; proinsulin,

Table 1 Sequences for qPCR

\begin{tabular}{|c|c|c|}
\hline & Species & Sequence \\
\hline \multicolumn{3}{|l|}{ Gene } \\
\hline \multirow[t]{6}{*}{ Hprt } & Rat & Forward: CGAGCCGACCGGTTCTG \\
\hline & & Reverse: CATAACCTGGTTCATCATCACTAATCAC \\
\hline & & Probe: CATGTCGACCCTCAGTCCCAGCG \\
\hline & Mouse & Forward: GATTGTTGAAGATATAATTGACACTGGTAA \\
\hline & & Reverse: GGGTCCTTTTCACCAGCAAG \\
\hline & & Probe: CAAACTTTGCTTTCCCTGGTTAAGCAGTACAGC \\
\hline \multirow[t]{6}{*}{ PC1 } & Rat & Forward: TTTGCTCTAGCCTTGGAAGC \\
\hline & & Reverse: ATACTCAGAGGTCCAGACAACCAGA \\
\hline & & Probe: CCAAATCTCACСTGGCGAG \\
\hline & Mouse & Forward: TCTGGTTGTCTGGACCTCTGAGT \\
\hline & & Reverse: CAAGССТGССССАTTCTTT \\
\hline & & Probe: CGACCCATTGGCCAGTAACCCAGG \\
\hline \multirow[t]{6}{*}{ Pc2 } & Rat & Forward: GACCTGGCGAGACATGCAA \\
\hline & & Reverse: TGAAGCTGGTTTCGCTTGG \\
\hline & & Probe: ATCTGACAGTGCTCACC \\
\hline & Mouse & Forward: CACСТCCAAGCGGAACCA \\
\hline & & Reverse: GCCAAAGAGGTGATTAAATTCCA \\
\hline & & Probe: CCGTCGCCACTGATGAACCTCATCA \\
\hline
\end{tabular}


mouse - Mm01259683, rat - Rn02121433; GPR120, mouse - Mm00725193, rat - Rn01759772; GPR119, mouse - Mm00731497, rat - Rn01648212 and TGR5, mouse Mm04212121, rat - Rn00710093)). Expression analyses of cell line and islet genes were made using mouse- or rat-specific primers and probes respectively. For quantification purposes, standard curves were generated using a serial dilution of known quantities of cDNA that express the gene of interest. Quantification of the RT-PCR signal was performed by the standard curve method, and the expression of each gene was normalised to the expression of HPRT.

\section{Regulation of GLP-1 and glucagon secretion}

Cells were seeded at $1 \times 10^{5}$ cells per well and incubated overnight. After preincubation for $30 \mathrm{~min}$ in KRB/HEPES (129 mmol/1 NaCl, $5 \cdot 0 \mathrm{mmol} / 1 \mathrm{NaHCO}_{3}, 4 \cdot 8 \mathrm{mmol} / 1 \mathrm{KCl}$, $1.2 \mathrm{mmol} / 1 \quad \mathrm{KH}_{2} \mathrm{PO}_{4}, 1.2 \mathrm{mmol} / 1 \quad \mathrm{MgSO}_{4}, 10 \mathrm{mmol} / 1$ HEPES, $\left.1.25 \mathrm{mmol} / 1 \mathrm{CaCl}_{2}, 0 \cdot 1 \% \mathrm{BSA}, \mathrm{pH} 7 \cdot 4\right)$ containing $25 \mathrm{mmol} / \mathrm{l}$ glucose, the cells were incubated as described. Glucagon was assessed by an enzyme immunoassay (CosmoBio, Tokyo, Japan) (with a detection limit of $20 \mathrm{fmol} / \mathrm{ml}$ ). Active GLP-1 was measured by ELISA (Linco Research, St Charles, Missouri, USA) (with a detection limit of $10 \mathrm{fmol} / \mathrm{ml}$ ). The specificity of both peptide assays was evaluated to ensure minimal cross-reactivity between glucagon, GLP-1 and their precursors. The cross-reactivity of GLP-1 in the glucagon assay was $8 \%$. Glucagon was not detected in the GLP-1 ELISA even at $1000 \mathrm{pM}$, and the cross-reactivity of inactive GLP-1 ${ }^{1-37}$ in the GLP-1 assay is $<3 \%$ (data not shown).

\section{Regulation of proglucagon processing in isolated islets}

Islets of Langerhans were prepared from male Han Wistar rats, as described previously (Ligon et al. 1998). Human islets were obtained from a donor and provided by the United Kingdom Human Tissue Bank (Leicester, UK) and isolated in the Islet Research Laboratory (Worcester, UK) in accordance with current ethical guidelines pertaining to the use of human tissue in research. Islets were incubated in RPMI-1640 media (Invitrogen) containing 10\% FCS, 1\% PSG and the indicated glucose concentration, at $37{ }^{\circ} \mathrm{C}$ and $5 \% \mathrm{CO}_{2}$ and moved into fresh media daily. Following 24 h, 3 or 7 days in culture, islets were collected for gene expression analysis, and islet protein extracts were prepared by lysis in Mammalian cell lysis buffer (Sigma) containing a complete protease inhibitor cocktail (Roche). The conditioned medium was also collected for GLP-1 and glucagon measurement.

\section{Glucose-stimulated insulin secretion}

Islets were picked 3 per well into 96-well plates containing $\mathrm{KRH}$ buffer and incubated for $30 \mathrm{~min}$ at $37^{\circ} \mathrm{C}$ and $5 \% \mathrm{CO}_{2}$. Islets were then stimulated with $20 \mathrm{mmol} / 1$ glucose for $2 \mathrm{~h}$. Secreted insulin levels were measured using an insulin homogenous time resolved fluorescence assay (Cisbio, Bagnols, France).
Western blot analysis of PC1

Extracts of 100 islets were prepared as described previously. Proteins were resolved by SDS-PAGE and proteins were transferred onto a nitrocellulose membrane. The membrane was blocked using a 5\% BSA and then incubated overnight with a PC1 antibody (1:500; a kind gift from Prof. John Creemers, University of Leuven, Belgium). Proteins were visualised using anti-rabbit HRP-conjugated antibody (Pierce, Rockford, IL, USA) and ECL detection reagents (Roche).

\section{Regulation of the PC1 promoter by L-cell activators}

A construct containing the nucleotide sequence corresponding to the 971 bp upstream of the PC1 transcription start site (Jansen et al. 1995) was synthesised by GeneArt (Toronto, ON, Canada). Cells were transiently transfected using Lipofectamine2000 (Invitrogen). Transfected cells were incubated for $24 \mathrm{~h}$ with small molecule agonists for GPR120, TGR 5 and GPR119 (a gift from AstraZeneca, Macclesfield, UK) and luciferase activity was assessed using BrightGlo assay kit (Promega).

\section{$S T Z$ treatment of islets in vitro}

Islets were cultured 10 per well in $0 \cdot 22 \mu \mathrm{m}$ filter plates (Millipore, Billerica, MA, USA). Medium was removed and replaced with $100 \mu \mathrm{l}$ of medium containing STZ (Sigma) at the concentrations indicated. Islets were incubated for $2 \mathrm{~h}$ at $37^{\circ} \mathrm{C}$ and $5 \% \mathrm{CO}_{2}$, after which the STZ was removed and replaced with $250 \mu$ culture medium (method adapted from Harb et al. (2007)). Islets were incubated for a period of $48 \mathrm{~h}$ with one medium change to remove all contaminants from cell apoptosis. Conditioned medium was collected and analysed for GLP-1 and glucagon. Islet function was assessed by GSIS assay.

\section{Statistical analysis}

Experiments were performed at least three times and results are presented as mean \pm s.E.M., and $P$ values were determined by the unpaired Student's $t$-test. Results were considered significant when $P<0 \cdot 05$.

\section{Results}

The prohormone convertase, PC1, is expressed in the $\alpha$ TC1-6 pancreatic $\alpha$-cell line

PC1 and PC2, the proteases known to cleave proglucagon (Fig. 1a), were found in both the $\alpha$ TC1-6 $\alpha$-cell line and the MIN6 $\beta$-cell line (Fig. $1 \mathrm{~b}$ and c), although expression of PC1 was several hundred fold higher in the $\beta$-cells, while PC2 was higher in the $\alpha$ TC1- 6 cells. Proglucagon was expressed in the pancreatic $\alpha$-cell lines, $\alpha$ TC1-6 and $\alpha$ TC1-9 (Fig. 1d), whereas insulin was not expressed but was found in the MIN6 $\beta$-cell line (Fig. 1e). 

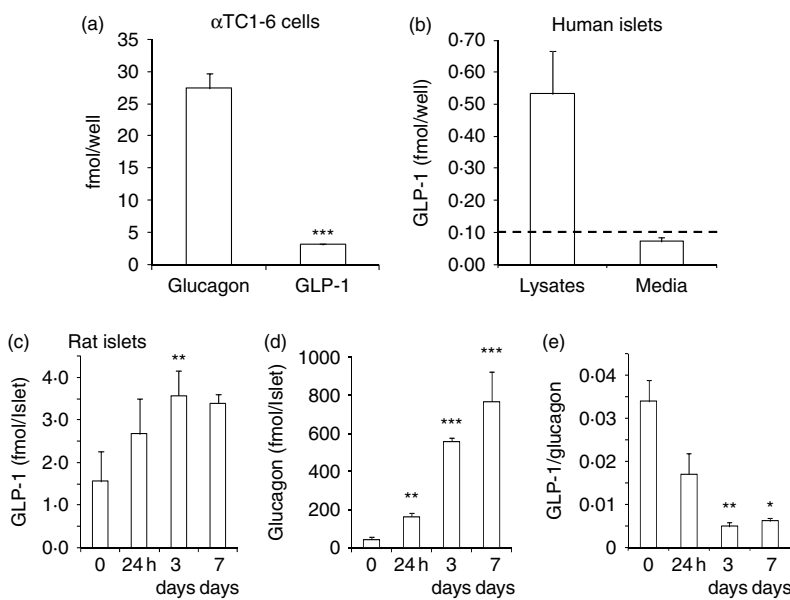

Figure 2 Secretion of glucagon and GLP- 1 from $\alpha$-cells and islets in culture. (a) Comparison of the basal release of glucagon and GLP-1 over a period of $30 \mathrm{~min}$ from $\alpha \mathrm{TC} 1-6$ cells. Data expressed as the mean \pm S.E.M. for five independent experiments. ${ }^{* * *} P<0 \cdot 001$. (b) Human islets have intracellular GLP-1 peptide. GLP-1 was measured in lysates from human islets and in culture media after $24 \mathrm{~h}$ under basal conditions. Levels in media were below the level of detection of the assay (dashed line). Data expressed as the mean \pm s.D. of three separate incubations. (c and d) Time course of production of GLP-1 and glucagon in rat islets. GLP-1 and glucagon were measured in extracts of freshly isolated islets, and in extracts from islets cultured for 1,3 and 7 days in media containing $5 \mathrm{mmol} / \mathrm{l}$ glucose. (e) The GLP-1 to glucagon ratio over the same time course shows the extent of change. Data expressed as the mean \pm S.E.M. expression of three separate incubations and are representative of three independent experiments. ${ }^{*} P<0 \cdot 05$, $* * P<0 \cdot 01, * * * P<0 \cdot 001$ significant increase in intracellular GLP-1 compared with freshly isolated islets.

GLP-1 is produced by pancreatic $\alpha$-cell lines and by human and rodent islets

The $\alpha$ TC1-6 cells secreted both GLP-1 and glucagon into culture medium after only $30 \mathrm{~min}$ incubation (Fig. 2a) with approximately tenfold higher concentrations of glucagon $(27 \cdot 3 \pm 2 \cdot 3$ vs $3 \cdot 1 \pm 0 \cdot 2 \mathrm{fmol} /$ well, $P<0 \cdot 001)$. GLP-1 peptide was also detected in human islets incubated for $24 \mathrm{~h}$ under basal conditions. However, the GLP-1 was only present in cell lysates and not in culture medium (Fig. 2b) suggesting it was either not secreted or the concentrations were below the limit of detection under these conditions.

GLP-1 was also detected in extracts of freshly isolated rat islets and concentrations increased from 1.5 to $3.5 \mathrm{fmol} /$ islet after incubation for 3 days in $5 \mathrm{mmol} / 1$ glucose (Fig. 2c). The same islets produced glucagon that increased to a greater extent over time in culture (Fig. $2 \mathrm{~d}$ and e).

\section{PC1 expression is increased by high glucose concentrations in rat islets}

PC1 gene expression was markedly increased by incubation with 11 and $25 \mathrm{mmol} / 1$ glucose in rat islets cultured for 3 days and expression levels remained elevated by day 7 in the islet cultures with high glucose concentrations (Fig. 3a). The active form of PC1 protein also shows a trend towards increased expression although this was not statistically significant (Fig. 3b). Proglucagon and PC2 mRNA levels did not alter in the rat islets cultured in high glucose over this time course (data not shown).

\section{High glucose stimulates GLP-1 secretion but inhibits glucagon secretion}

Glucagon secretion from $\alpha$ TC1-6 cells decreased as glucose concentrations increased from 0.5 to $35 \mathrm{mmol} / 1$ (Fig. 4a). A range of incubation times was investigated and $30 \mathrm{~min}$ chosen as optimal (data not shown). GLP-1 secretion was stimulated by high glucose $(25 \mathrm{mmol} / \mathrm{l})$ whereas glucagon secretion was inhibited (Fig. $4 b$ and c), suggesting that these peptides are released from $\alpha \mathrm{TC1}-6$ cells. $\mathrm{KCl}$, a wellestablished secretagogue for provoking the release of secretory vesicles from cells, caused an increase in release of both GLP-1 and glucagon (Fig. 4d and e).

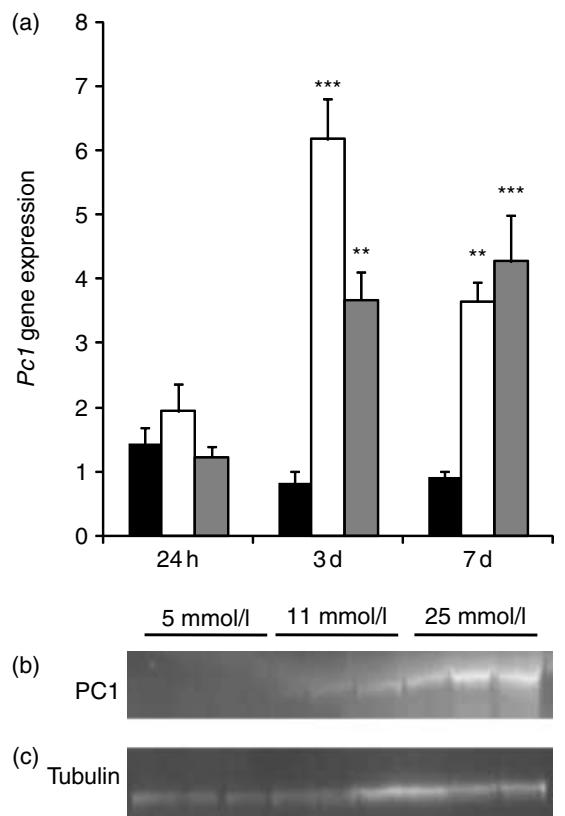

Figure 3 Effect of glucose on PC1 in cultured islets. (a) PC1 gene expression was measured in islets cultured in $5 \mathrm{mmol} / \mathrm{l}$ (black bars), $11 \mathrm{mmol} / \mathrm{l}$ (open bars) or $25 \mathrm{mmol} / \mathrm{l}$ (shaded bars) glucose for 1,3 or 7 days. Data are the mean expression \pm s.E.M. of three independent incubations normalised to HPRT. Each experiment was repeated three times ${ }^{* *} P<0 \cdot 01,{ }^{* * *} P<0 \cdot 001$. $P C 1$ gene expression shows a significant increase when incubated for 3 and 7 days with 11 and $25 \mathrm{mmol} / \mathrm{l}$ glucose compared with islets cultured in $5 \mathrm{mM}$ glucose. (b and c) Effect of glucose on PC1 protein. Western blots were carried out on lysates from rat islets (100 islets per incubation) cultured in 5, 11 and $25 \mathrm{mmol} / \mathrm{I}$ glucose for 7 days. PC1 protein was detected in the islet extracts (b) and a tubulin antibody was used to control for equal loading (c). 

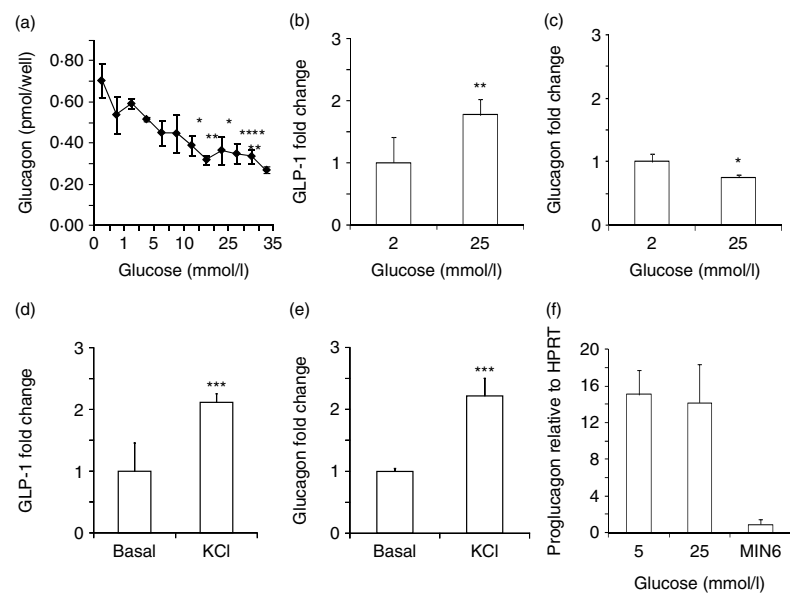

Figure 4 Effect of glucose on GLP-1 and glucagon in $\alpha$ TC1-6 cells. (a) Cells were incubated with a range of concentrations of glucose for 30 min and glucagon secretion was measured. (b-e) GLP-1 and glucagon secretion. Cells were incubated with either low $(2 \mathrm{mmol} / \mathrm{l})$ or high glucose $(25 \mathrm{mmol} / \mathrm{l})(\mathrm{b}$ and c). Cells were also incubated with $\mathrm{KCl}(40 \mathrm{mmol} / \mathrm{l})$ for $30 \mathrm{~min}$ ( $\mathrm{d}$ and e). Data expressed as the mean fold change \pm S.E.M. of at least four independent experiments. $* P<0 \cdot 05, * * P<0 \cdot 01,{ }^{* * *} P<0 \cdot 001$. (f) Effect of glucose on expression of proglucagon in $\alpha \mathrm{TC} 1-6$ cells. Cells were incubated for 5 days in low $(5 \mathrm{mmol} / \mathrm{l})$ and high $(25 \mathrm{mmol} / \mathrm{l})$ glucose before gene expression was assessed. Results are compared with the MIN6 pancreatic $\beta$-cell line. Data expressed as the mean \pm s.D. of three replicate RNA preparations.

Over the longer term (5 days), expression of the proglucagon gene was not affected by incubation with high glucose $(25 \mathrm{mmol} / \mathrm{l}$; Fig. $4 \mathrm{f})$ and there was no change in expression of either PC1 or PC2.

\section{$L$-cell GPCR ligands can increase GLP-1 release from pancreatic $\alpha$-cells}

In intestinal L-cells, secretion of GLP-1 is thought to be regulated by the GPCRs, GPR120, TGR 5 and GPR119, which are activated by specific agonists. We examined expression of these receptors on $\alpha \mathrm{TC} 1-6$ and $\alpha \mathrm{TC} 1-9$ cells to determine if there was variation in receptor expression and to identify the best cell line for the analysis of PC1 promoter regulation. While the L-cell line, STC-1, had much higher expression of TGR 5, $\alpha$ TC1- 6 cells expressed more GPR119 and GPR120 than the STC-1 cell line (Fig. 5).

In other endocrine tissues, such as intestine (Dhanvantari et al. 2001) and pituitary (Bloomquist et al. 1991, Li et al. 2001) expression of PC1 can be regulated. Therefore, we investigated whether PC1 promoter activity could be stimulated using transient transfection with a PC1 promoter linked to a luciferase construct. In both the control STC-1 and the $\alpha \mathrm{TC} 1-6$ cells, the PC1 promoter is increased by the combination of forskolin and IBMX (Fig. 5d). In the STC-1 cells, the increase in PC1 could affect secretion of other enteroendocrine peptides but in the pancreatic $\alpha$-cells it is likely to increase GLP-1.
Each of the GPCRs can be activated by their specific agonists in a dose-dependent manner in STC-1 cells (data not shown) and this was used to select concentrations of ligands to test on PC1 promoter activity in $\alpha$ TC1 -6 cells. Stimulation with a GPR120 agonist caused activation of the PC1 promoter in STC-1 cells but TGR5 and GPR 119 ligands had no effect (Fig. 5d). Therefore, we sought to determine if activation of these receptors would upregulate PC1 in $\alpha \mathrm{TC} 1-6$ cells. In this $\boldsymbol{\alpha}$-cell line, TGR 5 stimulation with a small molecule agonist (supplied by AstraZeneca) increased PC1 promoter activity to nearly the same extent as forskolin and IBMX, but GPR119 and GPR120 ligands had no effect. Secretion of GLP-1 was stimulated by GPR120 and TGR 5 agonists in the $\alpha$ TC1- 6
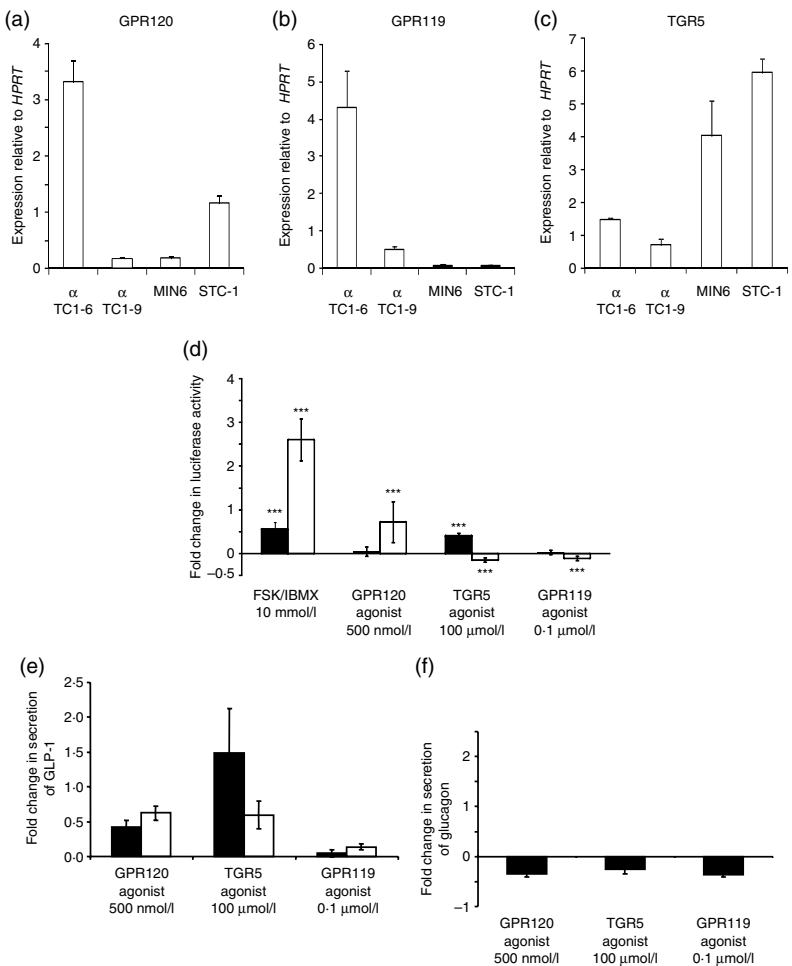

Figure 5 Expression and stimulation of L-cell GPCRs in $\alpha$ TC1-6 cells. (a-c) Gene expression was assessed in two $\alpha$-cell lines ( $\alpha$ TC16 and $\alpha \mathrm{TC} 1-9$ ), a $\beta$-cell line (MIN6) and an L-cell line (STC-1). Data expressed as the mean of triplicate wells \pm S.E.M., normalised to the housekeeping gene HPRT, and is representative of three experiments. (d) L-cell GPCR ligands stimulate the PC1 promoter in pancreatic $\alpha$-cells. $\alpha$ TC1- 6 cells (closed bars) and STC- 1 cells (open bars) were transiently transfected with a PC1 promoter/luciferase reporter gene. Cells were then incubated with the receptor ligands for $24 \mathrm{~h}$. Cells were lysed and the PC1 promoter-driven luciferase activity was measured in the cell supernatants. Data expressed as the mean fold change over basal \pm S.E.M. of at least three independent experiments. ${ }^{* * *} P<0 \cdot 001$. (e and f) L-cell GPCRs increase GLP-1 secretion from $\alpha \mathrm{TC} 1-6$ cells. Cells were incubated with receptor ligands for $2 \mathrm{~h}$. GLP-1 (e) and glucagon ( $\mathrm{f}$ ) secretion was measured from $\alpha \mathrm{TC} 1-6$ cells (closed bars) and STC- 1 cells (open bars; changes in glucagon release were undetectable from STC-1 cells). Data expressed as the mean fold change over basal \pm s.E.M. of at least three independent experiments. 
cells, while glucagon secretion was inhibited by all three agonists in the same cells (Fig. 5e and f).

\section{Damaged islets with decreased $\beta$-cell function have increased GLP-1 secretion}

To assess the effect of $\beta$-cell damage on GLP-1 secretion from $\alpha$-cells islets were treated with the $\beta$-cell toxin, STZ, for $2 \mathrm{~h}$ and then incubated for $48 \mathrm{~h}$ before assessing $\beta$-cell function (Fig. 6a). Islets treated with $0 \cdot 3$ and $1 \mathrm{mmol} / 1 \mathrm{STZ}$ had a $>50 \%$ decrease in GSIS when exposed to 10 and $20 \mathrm{mmol} / 1$ glucose.

Forty-eight hours after treatment with STZ there was a significant increase in GLP-1 secretion. STZ $(0 \cdot 1 \mathrm{mmol} / \mathrm{l})$ treatment resulted in a $2 \cdot 5$-fold increase in GLP-1 release from islets, while $0.3 \mathrm{mmol} / 1 \mathrm{STZ}$ produced a maximal response with a fourfold increase (Fig. 6b). Over the same concentration range there were no changes in the glucagon release from the islets (Fig. 6c).
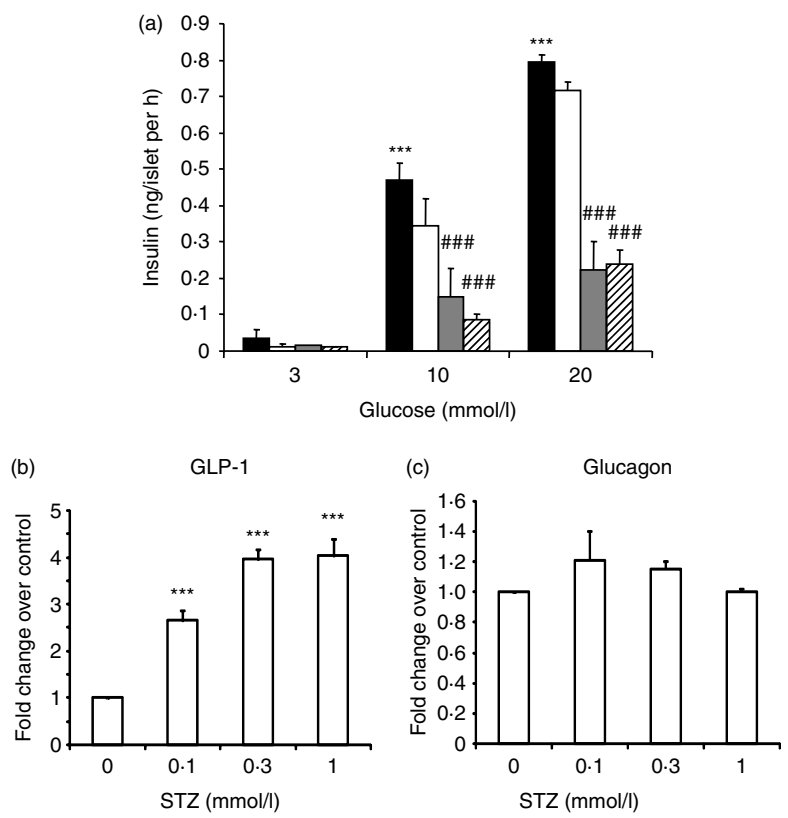

Figure $6 \beta$-Cell function in STZ-treated islets. (a) Rat islets (10 per well) were treated with increasing concentrations of STZ for $2 \mathrm{~h}$ and then left $48 \mathrm{~h}$. Islets were then stimulated with differing concentrations of glucose for $120 \mathrm{~min}$ and the secretion of insulin measured. Control islets (black bars), and islets treated with $0.1 \mathrm{mmol} / \mathrm{l} \mathrm{STZ}$ (white bars), $0.3 \mathrm{mmol} / \mathrm{l} \mathrm{STZ} \mathrm{(grey} \mathrm{bars)} \mathrm{and}$ $1 \mathrm{mmol} / \mathrm{l} \mathrm{STZ}$ (striped bars). Data expressed as the mean insulin secretion \pm S.E.M. of six replicate wells and is representative of three independent experiments. ${ }^{* *} P<0 \cdot 001$ shows significant increase in insulin secretion compared with $3 \mathrm{mM}$ glucose controls.

$\# \# P<0 \cdot 001$ shows significant decrease in insulin secretion from STZ-treated islet compared with control islets. (b and c) GLP-1 and glucagon release in response to STZ treatment of rat islets. Islets were treated with STZ as described earlier and then extracts and media collected $48 \mathrm{~h}$ later for measurement of GLP-1 (b) and glucagon (c) content using specific ELISAs. Data expressed as the mean fold change in peptide over vehicle-treated islets \pm s.E.M. of three independent experiments $* * * P<0 \cdot 001$.

\section{Discussion}

There is increasing interest in using GLP-1 analogues and DPPIV inhibitors as novel treatments for patients with diabetes. In part this is because of the recognised effects of GLP-1 in augmenting insulin release (Buteau et al. 2004). However, there is also data showing that GLP-1 can promote $\beta$-cell regeneration (Xu et al. 1999). In this paper, we provide evidence that $\alpha$-cells from the pancreas can produce GLP-1 and in certain situations there is upregulation of PC1 in $\alpha$-cell lines that would enable increased cleavage of proglucagon to GLP-1. By using STZ as a mechanism to impair $\beta$-cell function in rat islets, we show that GLP-1 secretion by $\alpha$-cells is upregulated while glucagon secretion is not altered. In the intestinal L-cells, GLP-1 release is stimulated by novel GPCR-related mechanisms. We have found that these receptors are present on $\boldsymbol{\alpha}$-cell lines and that GLP-1 secretion can be increased by activation of these receptor signalling pathways. Overall, these studies emphasise the importance of alternative processing of proglucagon in pancreatic $\alpha$-cells and the endogenous mechanisms enabling GLP-1 to have a paracrine effect on $\beta$-cell regeneration in the pancreas.

Although glucagon is the major product of the proglucagon gene in the $\alpha$ TC1- 6 cell line, the data presented shows that PC1 is expressed and that GLP-1 is produced and detectable in culture medium after only $30 \mathrm{~min}$ incubation. This is substantiated by the finding of GLP-1 along with glucagon and oxyntomodulin, using the more qualitative approach of intactcell mass spectrometry in $\alpha$ TC1-9 cells (Buchanan et al. 2007). In addition, GLP-1 is present in isolated human pancreatic islets cultured for $24 \mathrm{~h}$, raising the possibility that upregulation of this mechanism could provide GLP-1 for paracrine effects. GLP-1 is also found in rodent islets and there is an increase in the GLP-1 concentration when islets are kept in culture with a DPPIV inhibitor for 3-7 days. The concentration of GLP-1 detected in the rodent islet was $3.5 \mathrm{fmol} /$ islet, which was comparable to other studies (Thyssen et al. 2006). In the perfused rat pancreas concentrations as low as $50 \mathrm{pmol} / 1$ of GLP-1 have been shown to increase insulin secretion (Mojsov et al. 1987). Although this concentration is higher than that detected in this study, this may be reflective of the different concentrations required for exogenous ligand compared with a paracrine effect. As with the human islets, rodent islet GLP-1 could not be detected in the culture medium. This suggests that there could be specific mechanisms to stimulate release of GLP-1 from the $\alpha$-cells in the islets, although there is also the possibility that GLP-1 is secreted but the levels are below the limit of detection of the current assay. Active GLP-1 (GLP-1 (7-36)), is produced following cleavage of GLP-1 (1-36) by PC1 or furin, which are both expressed in the $\alpha$-cell. This GLP-1 has previously been found in normal isolated rat islets (Heller \& Aponte 1995, Masur et al. 2005). When the islets were cultured ex vivo for 7 days, significant levels of GLP-1 were found at an almost equimolar ratio to active glucagon (Masur et al. 2005). 
Significant increases in PC1 expression were also observed when rat islets were cultured in 11 and $25 \mathrm{mM}$ glucose, and this was substantiated by increased PC1 protein. The upregulation of PC1 in islets was not evident after $24 \mathrm{~h}$ but was observed after 3 and 7 days in culture. It may be that some increases in PC1 occurred in the islet $\boldsymbol{\alpha}$-cells, but these changes were obscured by the changes in PC1 that are known to occur in B-cells (Martin et al. 1994, Skelly et al. 1996). Previous studies have shown that high glucose concentrations cause upregulation of PC1, but not PC2 expression, when measured by microarray and luciferase assays in an $\alpha$-cell model (McGirr et al. 2005). These data suggest that proglucagon processing could be altered to produce increased levels of GLP-1, as a result of increasing expression of PC1 in $\alpha$-cells.

The increasing concentrations of glucose decreased glucagon as has been shown previously (McKinnon et al. 2006). $\alpha$-Cell lines have also been shown to produce GLP-1 when exposed to supraphysiological concentrations of glucose (McGirr et al. 2005). However, this study directly compared the effect of high concentrations of glucose on both GLP-1 and glucagon and indicated that there was decreased glucagon with a concomitant increase in GLP-1 secretion. Given that proglucagon is the precursor of both glucagon and GLP-1 it is interesting to speculate how glucose could increase secretion of one and decrease secretion of the other. Glucose could theoretically act at the level of synthesis of proglucagon and/or synthesis of either of the processing enzymes and/or release of secretory vesicles. Our hypothesis is that a subset of cells were secreting primarily GLP-1 (and the proglucagon fragment glicentin) and other cells were secreting primarily glucagon (and the precursor of GLP-1 (MPGF); see Fig. 1). This could explain why treatment with potassium chloride that causes non-specific release of all secretory granules (which should release peptides from all the cells) results in release of both glucagon and GLP-1. Overall, this study suggests that high glucose concentrations increase PC1 gene expression and stimulate release of GLP-1 from the $\alpha$ TC1- 6 cell line.

TGR5, GPR119 and GPR120 are three GPCRs, known to mediate GLP-1 release from L-cells (Hirasawa et al. 2005, Katsuma et al. 2005, Chu et al. 2007). Interestingly, we found that all three receptors were present in aTC1-6 cells, suggesting that signalling through these receptors could occur in the pancreatic $\boldsymbol{\alpha}$-cells as well as in the intestinal L-cells.

Since it is known that PC1 promoter activity can be regulated by factors that also regulate the hormone, which is cleaved by PC1 (Bloomquist et al. 1991, Jansen et al. 1995), we investigated activation of a transiently transfected PC1 promoter in pancreatic $\alpha \mathrm{TC} 1-6$ cells. Incubation with a small molecule agonist of TGR5 caused an increase in PC1 promoter-driven luciferase activity in the $\alpha \mathrm{TC} 1-6$ cells to a level similar to that observed with forskolin and IBMX. GLP-1 secretion was stimulated by the activation of TGR 5 and GPR120 but not by GPR119. Interestingly, glucagon secretion was not stimulated by any of these agonists. Therefore, GPCR activators can selectively increase GLP-1 release from pancreatic $\alpha$-cell lines.
It is likely that enabling the $\alpha$-cell to produce GLP-1 is a physiological response to high glucose concentrations, and may upregulate GLP-1 secretion to regenerate $\beta$-cell mass following a metabolic or inflammatory insult. Indeed, Kilimnik et al. (2010), show that PC1 and GLP-1 are present in the pancreatic $\boldsymbol{\alpha}$-cells of four mouse models of insulin resistance. This is supported by studies where PC1 was upregulated in $\boldsymbol{\alpha}$-cells after STZ treatment of rats in vivo (Nie et al. 2000, Thyssen et al. 2006). Wideman et al. (2009) provided elegant evidence that in mice subjected to STZ in vivo, transplantation of $\alpha$-cells expressing PC1 resulted in improved glucose tolerance. We sought to study this more directly and therefore developed an in vitro model, as described previously (Harb et al. 2007) whereby brief (2 h) treatment of isolated rat islets with STZ resulted in $\beta$-cell dysfunction in the form of a reduction in GSIS, glucagon remained to be secreted from the islets, suggesting the $\alpha$-cells remained functional. If the islets were then left for $48 \mathrm{~h}$ there was a rise in GLP-1 secretion that increased with increasing concentrations of STZ. Over the same time frame, the concentration of glucagon in the culture medium remained unchanged. This suggests that disruption of $\beta$-cell function is accompanied by an increase in the release of GLP-1. Taken together, these studies provide evidence that increased local production of GLP-1 in the pancreas may occur as a result of impaired $\beta$-cell function. The mechanism is unclear but could be because of a loss of tonic inhibition of insulin on GLP-1 production (Ding et al. 2009). Given that $\beta$-cells are interspersed with $\alpha$-cells in the human pancreas (Unger \& Orci 2010) this locally produced GLP-1 may have direct paracrine effects on the remaining $\beta$-cells to promote regeneration and proliferation. It would be important in future studies to find approaches to upregulating processing of proglucagon to GLP-1 in $\boldsymbol{\alpha}$-cells in patients with diabetes.

\section{Declaration of interest}

Dr D M S and Dr N M W are employed by AstraZeneca. The authors declare that there is no conflict of interest that could be perceived as prejudicing the impartiality of the research reported.

\section{Funding}

This work was supported by a Medical Research Council and AstraZeneca funded CASE studentship to N M W.

\section{Acknowledgements}

We are grateful to AstraZeneca for the gift of the GPCR agonists, and to Dianne Tibbs and Dr John Brennand from AstraZeneca for their support.

\section{References}

Bloomquist BT, Eipper BA \& Mains RE 1991 Prohormone-converting enzymes: regulation and evaluation of function using antisense RNA. Molecular Endocrinology 5 2014-2024. (doi:10.1210/mend-5-12-2014) 
Buchanan CM, Malik AS \& Cooper GJ 2007 Direct visualisation of peptide hormones in cultured pancreatic islet alpha- and beta-cells by intact-cell mass spectrometry. Rapid Communications in Mass Spectrometry 21 34523458. (doi:10.1002/rcm.3253)

Buteau J, El-Assaad W, Rhodes CJ, Rosenberg L, Joly E \& Prentki M 2004 Glucagon-like peptide-1 prevents beta cell glucolipotoxicity. Diabetologia 47 806-815. (doi:10.1007/s00125-004-1379-6)

Chu ZL, Jones RM, He H, Carroll C, Gutierrez V, Lucman A, Moloney M, Gao H, Mondala H, Bagnol D et al. 2007 A role for beta-cell-expressed G protein-coupled receptor 119 in glycemic control by enhancing glucosedependent insulin release. Endocrinology 148 2601-2609. (doi:10.1210/en. 2006-1608)

De Leon DD, Crutchlow MF, Ham JY \& Stoffers DA 2006 Role of glucagonlike peptide-1 in the pathogenesis and treatment of diabetes mellitus. International Journal of Biochemistry \& Cell Biology 38 845-859. (doi:10.1016/ j.biocel.2005.07.011)

Dhanvantari S, Izzo A, Jansen E \& Brubaker PL 2001 Coregulation of glucagon-like peptide-1 synthesis with proglucagon and prohormone convertase 1 gene expression in enteroendocrine GLUTag cells. Endocrinology 142 37-42.

Ding J, Gao Y, Zhao J, Yan H, Guo S, Zhang Q, Li L \& Gao X 2009 Pax6 haploinsufficiency causes abnormal metabolic homeostasis by downregulating glucagon-like peptide 1 in mice. Endocrinology 150 2136-2144. (doi:10.1210/en.2008-1006)

Edwards CM, Todd JF, Mahmoudi M, Wang Z, Wang RM, Ghatei MA \& Bloom SR 1999 Glucagon-like peptide 1 has a physiological role in the control of postprandial glucose in humans: studies with the antagonist exendin 9-39. Diabetes 48 86-93. (doi:10.2337/diabetes.48.1.86)

Hansen L, Deacon CF, Orskov C \& Holst JJ 1999 Glucagon-like peptide-1(7-36)amide is transformed to glucagon-like peptide-1-(9-36)amide by dipeptidyl peptidase IV in the capillaries supplying the $\mathrm{L}$ cells of the porcine intestine. Endocrinology 140 5356-5363. (doi:10.1210/en.140. 11.5356)

Harb G, Toreson J, Dufour J \& Korbutt G 2007 Acute exposure to streptozotocin but not human proinflammatory cytokines impairs neonatal porcine islet insulin secretion in vitro but not in vivo. Xenotransplantation 14 580-590. (doi:10.1111/j.1399-3089.2007.00427.x)

Heller RS \& Aponte GW 1995 Intra-islet regulation of hormone secretion by glucagon-like peptide-1-(7-36) amide. American Journal of Physiology 269 G852-G860.

Hirasawa A, Tsumaya K, Awaji T, Katsuma S, Adachi T, Yamada M, Sugimoto Y, Miyazaki S \& Tsujimoto G 2005 Free fatty acids regulate gut incretin glucagon-like peptide-1 secretion through GPR120. Nature Medicine 11 90-94. (doi:10.1038/nm1168)

Ionut V, Liberty IF, Hucking K, Lottati M, Stefanovski D, Zheng D \& Bergman RN 2006 Exogenously imposed postprandial-like rises in systemic glucose and GLP-1 do not produce an incretin effect, suggesting an indirect mechanism of GLP-1 action. American Journal of Physiology. Endocrinology and Metabolism 291 E779-E785. (doi:10.1152/ajpendo.00106.2005)

Irwin DM 2001 Molecular evolution of proglucagon. Regulatory Peptides 98 1-12. (doi:10.1016/S0167-0115(00)00232-9)

Jansen E, Ayoubi TA, Meulemans SM \& Van de Ven WJ 1995 Neuroendocrine-specific expression of the human prohormone convertase 1 gene. Hormonal regulation of transcription through distinct cAMP response elements. Journal of Biological Chemistry 270 15391-15397. (doi:10. 1074/jbc.270.19.11222)

Katsuma S, Hirasawa A \& Tsujimoto G 2005 Bile acids promote glucagon-like peptide-1 secretion through TGR 5 in a murine enteroendocrine cell line STC-1. Biochemical and Biophysical Research Communications 329 386-390. (doi:10.1016/j.bbrc.2005.01.139)

Kawamata Y, Fujii R, Hosoya M, Harada M, Yoshida H, Miwa M, Fukusumi S, Habata Y, Itoh T, Shintani Y et al. 2003 A G protein-coupled receptor responsive to bile acids. Journal of Biological Chemistry 278 9435-9440. (doi:10.1074/jbc.M209706200)

Kilimnik G, Kim A, Steiner DF, Friedman TC \& Hara M 2010 Intraislet production of GLP-1 by activation of prohormone convertase $1 / 3$ in pancreatic $\alpha$-cells in mouse models of $\beta$-cell regeneration. Islets 2 149-155. (doi:10.4161/isl.2.3.11396)
Larsen PJ \& Holst JJ 2005 Glucagon-related peptide 1 (GLP-1): hormone and neurotransmitter. Regulatory Peptides 128 97-107. (doi:10.1016/j.regpep. 2004.08.026)

Li QL, Jansen E, Brent GA \& Friedman TC 2001 Regulation of prohormone convertase 1 (PC1) by thyroid hormone. American Journal of Physiology - Endocrinology and Metabolism 280 E160-E170.

Ligon B, Boyd AE III \& Dunlap K 1998 Class A calcium channel variants in pancreatic islets and their role in insulin secretion. Journal of Biological Chemistry 273 13905-13911. (doi:10.1074/jbc.273.22.13905)

Martin SK, Carroll R, Benig M \& Steiner DF 1994 Regulation by glucose of the biosynthesis of PC2, PC3 and proinsulin in (ob/ob) mouse islets of Langerhans. FEBS Letters 356 279-282. (doi:10.1016/00145793(94)01284-9)

Masur K, Tibaduiza EC, Chen C, Ligon B \& Beinborn M 2005 Basal receptor activation by locally produced glucagon-like peptide- 1 contributes to maintaining beta-cell function. Molecular Endocrinology 19 1373-1382. (doi:10.1210/me.2004-0350)

McGirr R, Ejbick CE, Carter DE, Andrews JD, Nie Y, Friedman TC \& Dhanvantari S 2005 Glucose dependence of the regulated secretory pathway in alphaTC1-6 cells. Endocrinology 146 4514-4523. (doi:10.1210/ en.2005-0402)

McKinnon CM, Ravier MA \& Rutter GA 2006 FoxO1 is required for the regulation of preproglucagon gene expression by insulin in pancreatic alphaTC1-9 cells. Journal of Biological Chemistry 281 39358-39369. (doi:10. 1074/jbc.M605022200)

Mojsov S, Weir GC \& Habener JF 1987 Insulinotropin: glucagon-like peptide I (7-37) co-encoded in the glucagon gene is a potent stimulator of insulin release in the perfused rat pancreas. Journal of Clinical Investigation 79 616-619. (doi:10.1172/JCI112855)

Nie Y, Nakashima M, Brubaker PL, Li QL, Perfetti R, Jansen E, Zambre Y, Pipeleers D \& Friedman TC 2000 Regulation of pancreatic PC1 and PC2 associated with increased glucagon-like peptide 1 in diabetic rats. Journal of Clinical Investigation 105 955-965. (doi:10.1172/JCI7456)

Reimann F \& Gribble FM 2002 Glucose-sensing in glucagon-like peptide1-secreting cells. Diabetes 51 2757-2763. (doi:10.2337/diabetes.51.9. 2757)

Rouille Y, Westermark G, Martin SK \& Steiner DF 1994 Proglucagon is processed to glucagon by prohormone convertase PC2 in alpha TC1-6 cells. PNAS 91 3242-3246. (doi:10.1073/pnas.91.8.3242)

Skelly RH, Schuppin GT, Ishihara H, Oka Y \& Rhodes CJ 1996 Glucoseregulated translational control of proinsulin biosynthesis with that of the proinsulin endopeptidases PC2 and PC3 in the insulin-producing MIN6 cell line. Diabetes 45 37-43. (doi:10.2337/diabetes.45.1.37)

Thyssen S, Arany E \& Hill DJ 2006 Ontogeny of regeneration of beta-cells in the neonatal rat after treatment with streptozotocin. Endocrinology 147 2346-2356. (doi:10.1210/en.2005-0396)

Tucker JD, Dhanvantari S \& Brubaker PL 1996 Proglucagon processing in islet and intestinal cell lines. Regulatory Peptides 62 29-35. (doi:10.1016/01670115(95)00167-0)

Unger RH \& Orci L 2010 Paracrinology of islets and the paracrinopathy of diabetes. PNAS 107 16009-16012. (doi:10.1073/pnas.1006639107)

Wideman RD, Gray SL, Covey SD, Webb GC \& Kieffer TJ 2009 Transplantation of PC1/3-expressing alpha-cells improves glucose handling and cold tolerance in leptin-resistant mice. Molecular Therapy 17 191-198. (doi:10.1038/mt.2008.219)

Xu G, Stoffers DA, Habener JF \& Bonner-Weir S 1999 Exendin-4 stimulates both beta-cell replication and neogenesis, resulting in increased beta-cell mass and improved glucose tolerance in diabetic rats. Diabetes $\mathbf{4 8}$ 2270-2276. (doi:10.2337/diabetes.48.12.2270)

Received in final form 18 July 2011

Accepted 27 July 2011

Made available online as an Accepted Preprint 27 July 2011 